\title{
Ion Channel
}

National Cancer Institute

\section{Source}

National Cancer Institute. Ion Channel. NCI Thesaurus. Code C16754.

A transmembrane pore that presents a hydrophilic channel for ions to cross a lipid bilayer down their electrochemical gradients. Some degree of ion specificity is usually observed and typically a million ions per second may flow. Channels may be permanently open, like the potassium leak channel or they may be voltage gated, like the sodium channel or ligand gated like the acetylcholine receptor. 